\title{
Interactions of tuna fisheries with the Galápagos marine reserve
}

\author{
Kristina Boerder*, Andrea Bryndum-Buchholz, Boris Worm \\ Biology Department, Dalhousie University, Halifax, Nova Scotia B3H 4R2, Canada
}

\begin{abstract}
The largest protected areas of any kind have all recently been established in the ocean. Since 2012, 5 protected areas that exceed 1 million $\mathrm{km}^{2}$ in size have been created, mostly in remote oceanic areas. The potential conservation and fisheries benefits of such reserves have been debated in the public, the media, and the scientific literature. Little is known about their effectiveness for commercially valuable pelagic predators, especially for highly migratory species such as tuna and billfishes. Here we analyse the iconic Galápagos Marine Reserve, documenting interactions with and changes in associated tuna purse seine fisheries in the Eastern Tropical Pacific. Using a combination of long-term onboard observer data and a novel data set of high-resolution, remotely sensed vessel tracks (Automatic Identification System [AIS]), we reveal progressive divergence of tuna fishing effort, catch, and catch per unit of effort (CPUE) trends in areas adjacent to the reserve from trends in the surrounding fished areas. Both data sets show a regionally unique hotspot of concentrated effort along the western reserve boundary now receiving $>4$-fold greater fishing effort density than the rest of the surrounding area. These dynamic interactions of tuna purse seine fisheries with the Galápagos Marine Reserve suggest that the reserve might enhance fish stock availability to local fisheries and help to stabilize local catches despite overall decreasing biomass trends for these highly commercial tuna stocks.
\end{abstract}

KEY WORDS: Marine protected area $\cdot$ Pelagic fisheries · Tuna · AIS · FADs · Purse seine

${ }^{*}$ Corresponding author: kristina.boerder@dal.ca

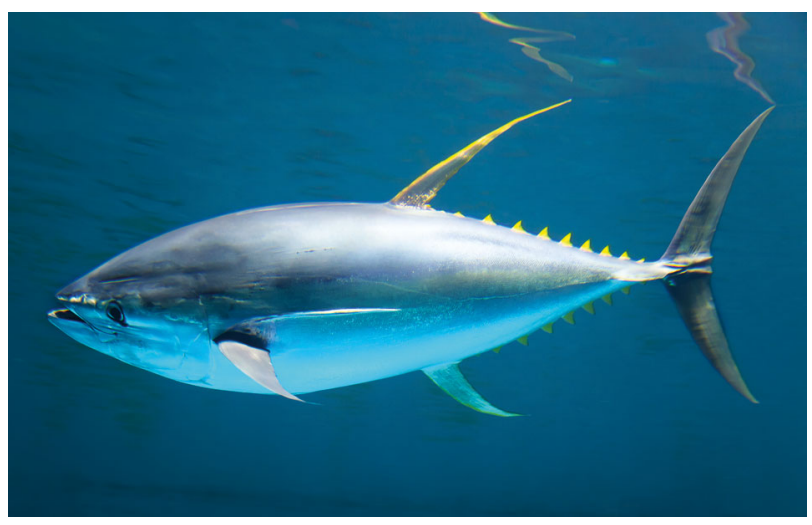

Spatial protection by the Galápagos Marine Reserve benefits yellowfin tuna stocks and associated pelagic fisheries in the Eastern Tropical Pacific.

Photo: Shutterstock

\section{INTRODUCTION}

Growing concerns about the state of marine biodiversity and its resources have provided incentive for the creation of large-scale marine protected areas (MPAs), which have increased greatly in number and size in recent years (Lubchenco \& Grorud-Colvert 2015). A protected area, according to the definition by IUCN, is a clearly defined geographical space, recognised, dedicated and managed, through legal or other effective means, to achieve the long-term conservation of nature with associated ecosystem services and cultural values (Dudley 2008). Since 2012 alone, 5 MPAs larger than $1000000 \mathrm{~km}^{2}$ have been created and collectively protect an area that is significantly larger than all MPAs gazetted in the

() The authors 2017. Open Access under Creative Commons by Attribution Licence. Use, distribution and reproduction are unrestricted. Authors and original publication must be credited. 
previous 125 yr. Just in 2016, the expansion of the Papahānaumokuākea Marine National Monument in Hawaii followed by the declaration of the Ross Sea Marine Protected Area off Antarctica created the world's largest protected areas of any kind, land or sea, covering $>1.5$ million $\mathrm{km}^{2}$ each. Declarations of further large MPAs such as the Rapa Nui Rahui MPA around Easter Island, Chile, followed in 2017. This recent trend has sparked a discussion about the benefits and challenges of large scale protection for key stakeholders such as fisheries (Wilhelm et al. 2014). While some conservation benefits of large MPAs have been addressed in previous studies (e.g. White et al. 2017), the role of large MPAs for fisheries management remains unclear especially in the context of pelagic fisheries operating outside of reserve boundaries (Roberts et al. 2001, Forcada et al. 2008). It has been suggested that large MPAs can be an effective conservation tool, even for some pelagic species (Edgar et al. 2014), particularly when placed around vulnerable aggregation sites such as nursery or spawning grounds (Gell \& Roberts 2003). While there are studies showing benefits of marine reserves for some small-scale fisheries in coastal areas, these mostly concern resident species such as lobster (Kelly et al. 2000, Follesa et al. 2011), scallops (Murawski et al. 2000), clams (Tawake et al. 2001), or reef fishes (McClanahan \& Mangi 2000, Stobart et al. 2009, da Silva et al. 2015, Tewfik et al. 2017). Effects of MPAs or other spatial closures on highly mobile predators such as tuna or billfish are more elusive (Jensen et al. 2010, Grüss et al. 2011, Edgar et al. 2014). Due to the migratory nature of these oceanic species, they are within reach of open-ocean fisheries for most of their lives, potentially contributing to documented declines (Juan-Jordá et al. 2011, Myers \& Worm 2003, Pons et al. 2017), range contractions (Worm \& Tittensor 2011), and heightened extinction risk for some long-lived high-value species (Collette et al. 2011). Marine reserves are often thought to be too small to provide sufficient range coverage (Hyrenbach et al. 2000, Gell \& Roberts 2003, Breen et al. 2015) and, consequently, substantial benefits for highly migratory species and associated fisheries.

Understanding the interactions between large MPAs and marine fisheries could significantly advance our comprehension of MPA effectiveness as a conservation and management tool (Horta e Costa et al. 2013, Stevenson et al. 2013). On one hand, MPAs that disallow fishing might simply displace effort to other areas that may then be subject to overfishing (Halpern et al. 2004). On the other hand, and particularly if an area has been heavily fished prior to pro- tection, MPA establishment could initiate rebuilding of resident stocks that might then lead to spillover, here defined as the net emigration of organisms across the reserve boundary (Buxton et al. 2014). Over time, increasing spillover of rebounding stocks may also increase catches in adjacent fishing grounds (Gell \& Roberts 2003, Murawski et al. 2005). Fishermen tend to capitalize on this phenomenon by fishing along reserve boundaries, a behaviour known as 'fishing the line' (Rijnsdorp et al. 1998, Johnson et al. 1999, Russ \& Alcala 2011, Alemany et al. 2013, Van Der Lee et al. 2013). This pattern has been documented in several theoretical studies but empirical evidence is mostly available for small-scale marine reserves or temporal fisheries closures (Murawski et al. 2005, Kellner et al. 2007, Goñi et al. 2008, Stobart et al. 2009, Van Der Lee et al. 2013).

Anecdotal evidence from the Galápagos archipelago suggests that industrial purse seine vessels are 'fishing the line' for tuna around the Galápagos Marine Reserve, and that Ecuadorian tuna fishermen are changing their fishing habits and are now supporting the reserve as a perceived tuna spawning and nursery area (Kliffen \& Berkes 2015). These recent developments follow a long history of tuna fishing in Ecuador and around the Galápagos islands that began in the 1920 s with commercial purse seiners from California and later Japan targeting mainly yellowfin Thunnus albacares, bigeye Thunnus obesus and skipjack tuna Katsuwonus pelamis. Following legislative changes and Ecuador's claiming of the 200 nautical mile Exclusive Economic Zone (EEZ), tuna fisheries became more restricted. However, tuna was still caught around the islands by purse seiners and from the 1960s on by longliners, until the passage of the Special Law in 1998 banning commercial fishing within the Galápagos Marine Reserve (Oxford et al. 2009). This was mainly motivated by increasing conflicts between commercial purse seine fishing vessels and the growing tourism industry as well as local fishermen (Kliffen \& Berkes 2015). In recent years, the fishery has been dominated by vessels flagged to Ecuador and Mexico as well as a number of other South American countries with 272 active purse seiners licensed by the Inter-American Tropical Tuna Commission (IATTC) for the Eastern Tropical Pacific. IATTC stock assessment models estimate that overfishing is not occurring for the 3 main tuna species with reported catches close to maximum sustainable yield (yellowfin; Minte-Vera et al. 2014) or below (bigeye and skipjack; Aires-da-Silva \& Maunder 2014, Maunder 2014). With the establishment of the Galápagos Marine Reserve in 1998, industrial tuna 
fisheries were banned within a 40 nautical mile radius around the Galápagos islands. This was only the second large MPA to be declared worldwide (after the Great Barrier Reef Marine Reserve in Australia). It provides a valuable case study because it meets at least 4 of the 5 key so-called NEOLI features (sensu Edgar et al. 2014) that best predict protected area effectiveness worldwide, specifically no-take regulations (industrialized fisheries are banned inside the Galápagos Marine Reserve; artisanal fisheries are allowed), age (18 yr of protection), large size $\left(\sim 133000 \mathrm{~km}^{2}\right)$, and isolation from the mainland (Edgar et al. 2014). The fifth key feature (enforcement) was weak at the time of reserve implementation in 1998, but improved after 2002 (Castrejón \& Charles 2013, Kliffen \& Berkes 2015). Examining interactions between the Galápagos Marine Reserve and associated tuna purse seine fishery prior and subsequent to reserve enforcement represents an unparalleled opportunity to empirically document changes in tuna fisheries associated with a largescale MPA.

Considering reports of increasing support for the Galápagos Marine Reserve among tuna fishermen (Kliffen \& Berkes 2015), we attempted to quantify interactions between the Galápagos Marine Reserve and associated tuna fisheries from 2 complementary data sources: detailed catch and effort data including data on the use of fish aggregating devices (FADs) from the Inter-American Tropical Tuna Commission on-board observer program (henceforth referred to as IATTC observer data) and satellite-based vessel position data, delivered by Automatic Identification Systems (AIS) for purse seine vessels in the wider area around the Galápagos Marine Reserve (Fig. 1). We hypothesised that purse seine fisheries adjacent to the Galápagos Marine Reserve will exhibit different trajectories subsequent to reserve establishment when compared to surrounding waters, due to interactions with the reserve.

\section{MATERIALS AND METHODS}

\section{Study area}

We selected a large bounding box between $97^{\circ} \mathrm{W}$, $6^{\circ} \mathrm{S}, 85^{\circ} \mathrm{W}$ and $6^{\circ} \mathrm{N}$ around the Galápagos Islands as our study area, which includes the Galápagos Marine Reserve and the majority of the Ecuadorian EEZ around the islands totalling $>1.7$ million $\mathrm{km}^{2}$. This area was subdivided into $1^{\circ} \times 1^{\circ}$ cells, corresponding to the aggregation of the IATTC observer data used in this study (Fig. 1). For further study, a hotspot comprising 21 cells was determined west and southwest of the Galápagos Marine Reserve based on highest intensity fishing effort as seen from IATTC and AIS data (Figs. 1 \& 2).

\section{Data sources}

IATTC observer, FAD, and stock assessment data

Scientific fisheries observer data were obtained from the Inter-American Tropical Tuna Commission (IATTC) for the tuna purse seine fishery (vessels with >363 mt carrying capacity) in the Eastern Tropical Pacific for the years 1990 to 2015. Only fishing trips with observers on board are included in the dataset, which represent $86 \%$ of the total fishing effort in the tuna purse seine fishery within the respective vessel capacity during the study period. The data set contains information for each purse seine set, aggregated by month and $1^{\circ} \times 1^{\circ}$ grid cell. Each record includes year, month, and the coordinates for the respective grid cell location of the set, the number of sets, and the total catch by species (catch and discards of tuna and non-tuna species). Catch-per-uniteffort (CPUE) was calculated as the total catch per cell per year divided by the number of fishing sets in that cell and year. Raw data by year are displayed in Fig. S1 in the supplement at www.int-res.com/ articles/suppl/m585p001_supp.pdf.

Data on the use of FADs was obtained from IATTC for the years 1990 to 2015. This data set includes information on number of sets per area, month, and year as well as set types and total catch by species.

These data provide a coarse-resolution view of spatial and temporal patterns in observed fishing effort and catch. To compare broader trends in catch rates with those in recruitment and biomass, stock assessments for principal tuna species as published by IATTC were accessed and digitized. These data provide assessment-model based estimates of annual recruitment and spawning stock biomass ratios relative to the estimated virgin biomass that would exist without fishing.

\section{AIS data}

The AIS is a maritime safety tool intended to prevent ship collisions. Since 2004, AIS transponders are mandatory for all fishing vessels larger than 300 gross tonnage on international voyages (Interna- 

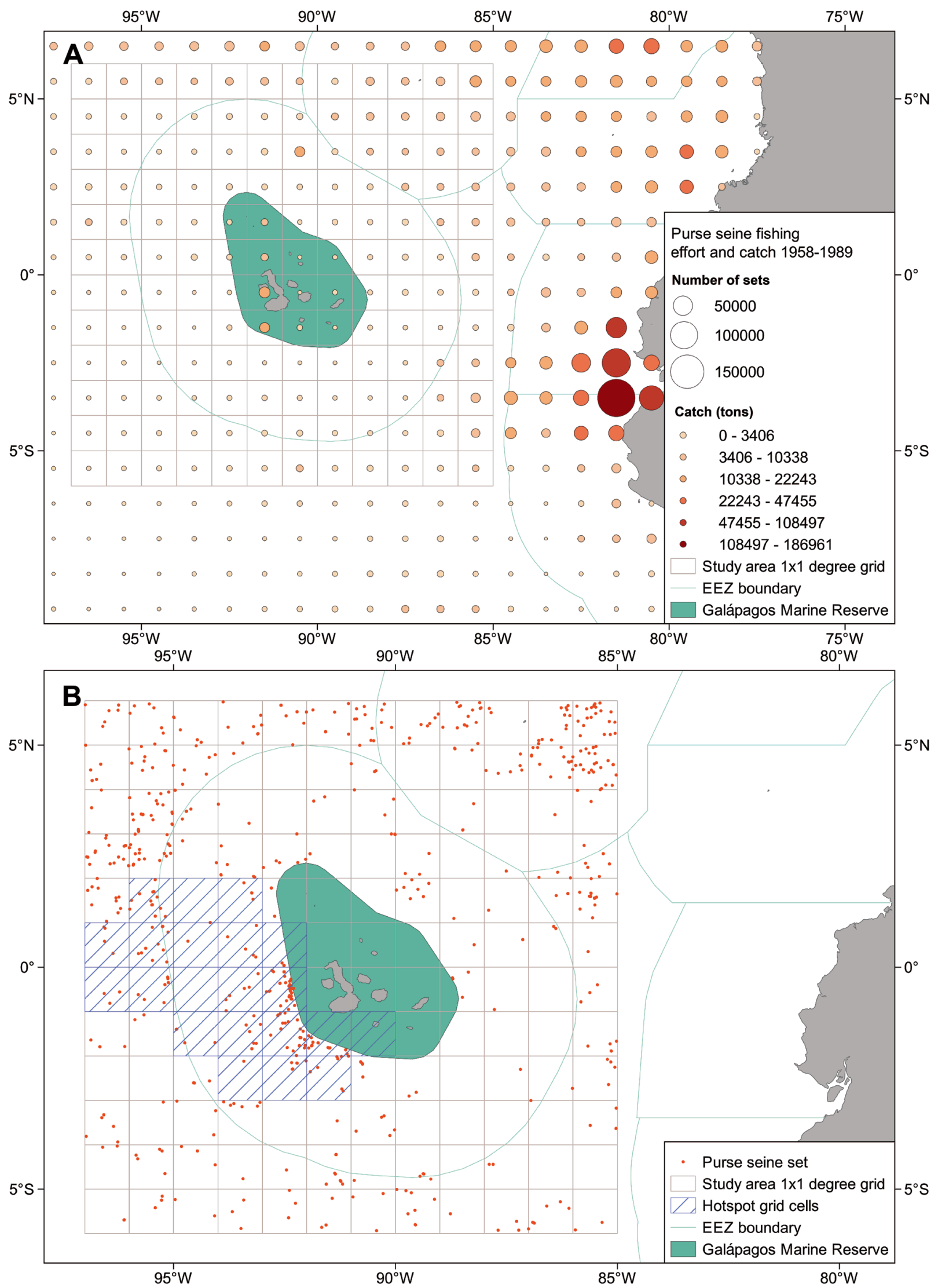
Fig. 1. Tuna fisheries in the study area. Shown is the marine area around the Galápagos Islands, Eastern Tropical Pacific on a $1^{\circ} \times 1^{\circ}$ latitude by longitude grid with the current marine reserve highlighted in green and exclusive economic zones outlined in light blue. (A) Historical fishing effort and catch prior to the study period and reserve establishment (1958-1989); (B) positions of purse seine fishing sets identified from AIS data for 49 vessels operating within the study area from January 2011 to October 2015 (red dots). Note the aggregation of sets along the western marine reserve boundary and around the western Galápagos Exclusive Economic Zone (a fishery 'hotspot' is indicated by hatched area, see data in Fig. 2). Map data from Natural Earth and MarineRegions.org, Galápagos Marine Reserve shapefile from UNEP-WCMC and IUCN (2016)

tional Maritime Organization [IMO] - Safety of Life at Sea Convention Chapter V, Annex 17). The AIS transponder transmits position and ship identification data at regular intervals to surrounding ships carrying receivers. Signals are also picked up by ground stations carrying receivers and by AIS-equipped satellites in whose field of view the ship is located. The receiving stations transmit the data to a processing centre. A complete transmitted AIS message contains, amongst other information, the ship's Maritime Mobile Service Identity, IMO number, call sign, speed and course over ground, position, rate of turn, and possibly the destination, the ship name, and the type of vessel. With these high-resolution data, the finescale movements of each vessel carrying an AIS transponder can be visualised (de Souza et al. 2016, McCauley et al. 2016).

Data for each vessel present in the study area between January 2011 and October 2015 with > 200 AIS detections were extracted from a database containing AIS data from the commercial provider exactEarth (www.exactearth.com). Through comparison with international fleet registries (International Maritime Organization Global Integrated Shipping Information System, https://gisis.imo.org) and regional fisheries management organisation vessel register lists (IATTC Regional Vessel Register, https://www. iattc.org/VesselRegister/VesselList.aspx?List=Reg Vessels\&Lang=ENG) using Maritime Mobile Service Identity and IMO numbers, we identified all purse seine fishing vessels active in the study area for further analysis.

\section{Data analyses}

\section{IATTC observer data}

Spatial autocorrelation in the observer data time series was tested for using Moran's I test for spatial autocorrelation as used in the spdep-package in the $\mathrm{R}$ statistical computing environment ( $\mathrm{R}$ v.1.0.136). Spatial clustering of fishing effort, catch, and CPUE was analysed conducting a hot spot analysis based on the Getis-Ord $G_{i}{ }^{*}$ statistic as implemented in ArcGIS 10.1. This method tests the null hypothesis that spatial association between neighbouring high ('hotspots') or low ('coldspots') values is due to random clustering and is given as:

$$
G_{i}^{*}=\frac{\sum_{j=1}^{n} W_{i, j} X_{j}-\bar{x} \sum_{j=1}^{n} W_{i, j}}{S \sqrt{\frac{\left[n \sum_{j=1}^{n} W_{i, j}^{2}-\left(\sum_{j=1}^{n} W_{i, j}\right)^{2}\right]}{n-1}}}
$$

where $x_{j}$ is the attribute value for feature $j, w_{i, j}$ is the spatial weight between the features $i$ and $j, n$ is equal to the total number of features, and

and

$$
\bar{X}=\frac{\sum_{j=1}^{n} x_{j}}{n}
$$

$$
S=\sqrt{\frac{\sum_{j=1}^{n} x_{j}^{2}}{n}}
$$

Based on a nearest-neighbor approach, local patterns of fishing effort and catch patterns are identified and compared to what is generally observed across the whole study area.

Neighbourhoods were defined by polygon contiguity (common boundary). As a result, the Getis-Ord $G_{i}{ }^{*}$ statistic returns $z$-scores (also known as standard scores), which give information about whether the observed clustering between neighbouring points can be attributed to random spatial processes, given their distance and value relative to the mean. A high positive $z$-score $(>+1.65)$ represents statistically significant spatial clustering of high values (hotspot); a low negative $z$-score $(<-1.65)$ represents statistically significant spatial clustering of low values (coldspot). A $z$-score near zero indicates no apparent spatial clustering.

To explore changes in spatial clustering over time, the data were bisected into two 8 yr intervals: 1990-2002 and 2003-2015. The year 2002 represents an even split of the time series and coincides with the time of improved reserve enforcement that ended widespread illegal fishing (Kliffen \& Berkes 2015) several years after designation of the Galápagos Marine Reserve. Using the nominal date of designation (1998) as a split point returns similar results. 
Long-term temporal trends in fishing effort, catch, and CPUE were approximated using local polynomial regression. The annual total across all cells in the study area was calculated and log-transformed to account for overdispersion. To test for significant differences between time trends in the hotspot and the study area, repeated-measures ANOVAs were performed. Separate repeated-measures ANOVAs were run for each of our variables of interest (fishing effort, catch, and CPUE), which were included as dependent variables. Location (grid cell) was included in each model as a single repeated measures factor with 2 levels (hotspot and study area).

Data for temporal trends of relative annual recruitment and spawning biomass ratio of yellowfin tuna were extracted from Minte-Vera et al. (2014) using WebPlotDigitizer v.3.12. Yellowfin tuna spawning biomass ratio as well as CPUE data were not normally distributed (Shapiro-Wilk normality test $\mathrm{p}=$ 0.004 and $\mathrm{p}=0.002$, respectively). Hence a nonparametric Spearman's rank correlation test was conducted using R v.1.0.136 to contrast annual CPUE and spawning biomass ratio.

\section{FAD data}

The data on the use of FADs were split into 2 time series, 1990-2002 and 2003-2015, using 2002 as the split point as explained above for the IATTC observer data. Sets were summarized by set type (dolphinassociated, not associated, or floating object [FAD] associated) and location (grid cell).

\section{AIS data}

Fishing set locations were extracted from the AIS data using the purse seine algorithm for satellite AIS data developed by de Souza et al. (2016). Briefly, this algorithm identifies fishing events based on low vessel speed ( $<2.5$ knots) and operational time (daylight only), with an accuracy of $97 \%$ against expertlabelled data (de Souza et al. 2016). Strings of continuous fishing activity were grouped into bursts and identified as individual sets based on the average set length as denoted by Walker \& Bez (2010) with a minimum set time of $10 \mathrm{~min}$.

To analyse the distribution of sets in relation to the reserve, set locations and their distance to the boundary were calculated and binned into areas of increasing distance of 0-10 km, 10-20 km, 20-50 km, 50-100 km, 100-200 km, and 200-400 km. A near- est-neighbour analysis was conducted to test for spatial autocorrelation using the Nearest Neighbour Index in QGIS 2.18. To compare fishing effort as seen from IATTC and AIS data, a hotspot analysis using AIS data was based on the hotspot for fishing effort as determined from the IATTC observer data from 2003 to 2015 including 21 cells with a significantly higher positive $z$-score as described above and shown in Fig. 1 (hatched area).

\section{RESULTS}

\section{IATTC observer data}

Statistically significant clusters of $1^{\circ} \times 1^{\circ}$ cells of high catch, fishing effort, and catch-per-unit-effort (CPUE) were identified for the time period prior to reserve enforcement (1990-2002) to the northwest, northeast, and (for catch and effort only) south of the Galápagos Marine Reserve (Fig. 2; Z-scores > 1.65). For the period after Galápagos Marine Reserve designation and enforcement (2003-2015), catch, fishing effort, and CPUE all clustered around a large, statistically significant fishery 'hotspot' directly adjacent to the western and southwestern Galápagos Marine Reserve boundary (Fig. 2; $z$-scores $>1.65$ ). This hotspot is located downstream of the reserve given the prevailing east-west currents. Coldspots of lower than expected catch, fishing effort, and CPUE were more consistently located to the south and southeast of the Galápagos archipelago (Fig. 2; Z-scores < $-1.65)$.

In addition to the spatial clustering of catch, fishing effort, and CPUE, we observed progressive divergence of temporal trends in tuna fishing that coincided with Galápagos Marine Reserve enforcement (Fig. 3). Catch and fishing effort increased throughout the study period in the study area (Fig. 3A: $\mathrm{r}^{2}=$ 0.75 , 3B: $r^{2}=0.77$ ), and CPUE showed a less consistent increase over the same time period (Fig. 3C: $\mathrm{r}^{2}=$ 0.65), with an initial increase followed by a decrease. This CPUE pattern is mirrored by recruitment and biomass data from regional IATTC stock assessments, with strong correlation between observed CPUE and assessed spawning stock biomass (Spearman's rank correlation, $\mathrm{p}=0.01484$, Fig. $\mathrm{S} 2$ in the Supplement). Overall trends in recruitment, biomass, and CPUE are similar across principal tuna species and thought to reflect large-scale oceanographic changes that drive variations in stock productivity (Aires-da-Silva \& Maunder 2014, Minte-Vera et al. 2014). 


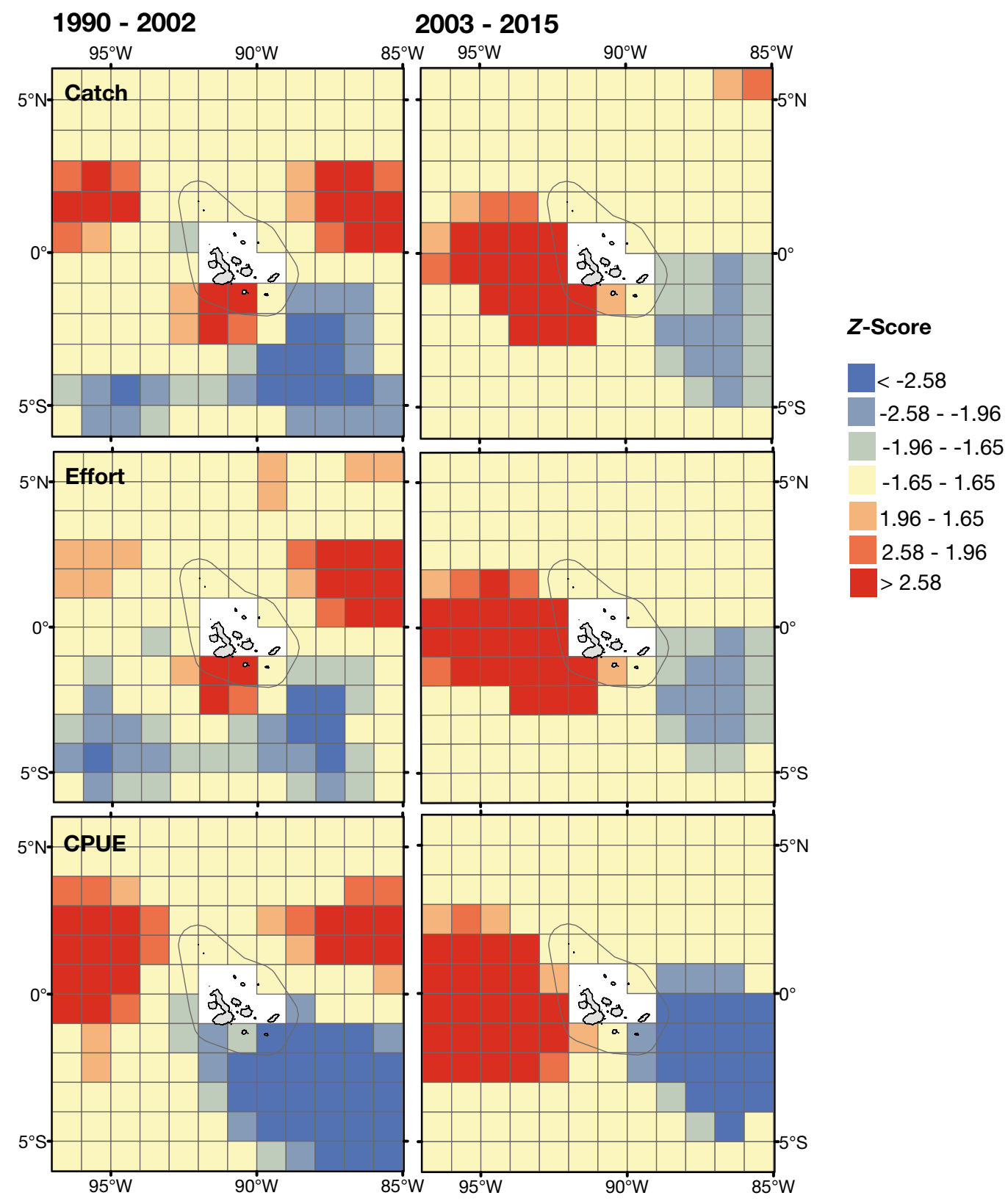

Fig. 2. Spatial trends in IATTC tuna fishing observer data. Clustering of purse seine catch, fishing effort, and CPUE were identified by conducting a hotspot analysis around the Galápagos Marine Reserve for the years 1990-2002 (left panels) and 2003-2015 (right panels). Z-scores less than -1.65 denote statistically significant coldspots (blue). $Z$-scores $>1.65$ indicate statistically significant hotspots (red). Galápagos Marine Reserve boundary is shown as a black outline around the Galápagos Islands. Note the concentration of effort, catch and CPUE hotspots downstream of the Galápagos Marine Reserve $2002-2015$. Raw data are displayed in Fig. S1. Map data from Natural Earth and MarineRegions.org, Galápagos Marine Reserve shapefile from UNEP-WCMC and IUCN (2016)

Comparing time trends of catch, fishing effort, and CPUE in the hotspot and the remaining study area, both catch and fishing effort showed a significantly larger increase within the hotspot over time (repeatedmeasures ANOVA: catch: $F=10.55, \mathrm{p}=0.0033, \mathrm{n}=$ 26; fishing effort: $F=7.46, \mathrm{p}=0.0114, \mathrm{n}=26$; CPUE: $F=9.415, \mathrm{p}=0.0052, \mathrm{n}=26)$. With respect to the tim- ing of Galápagos Marine Reserve enforcement across the whole study area, we observed an average increase of $52 \%$ in catch and $75 \%$ increase of fishing effort per $1^{\circ} \times 1^{\circ}$ grid cell, respectively, after designation and enforcement of the Galápagos Marine Reserve (2003-2015) relative to 1990-2002. Over the same time frame, CPUE decreased by $<1 \%$. Further, 

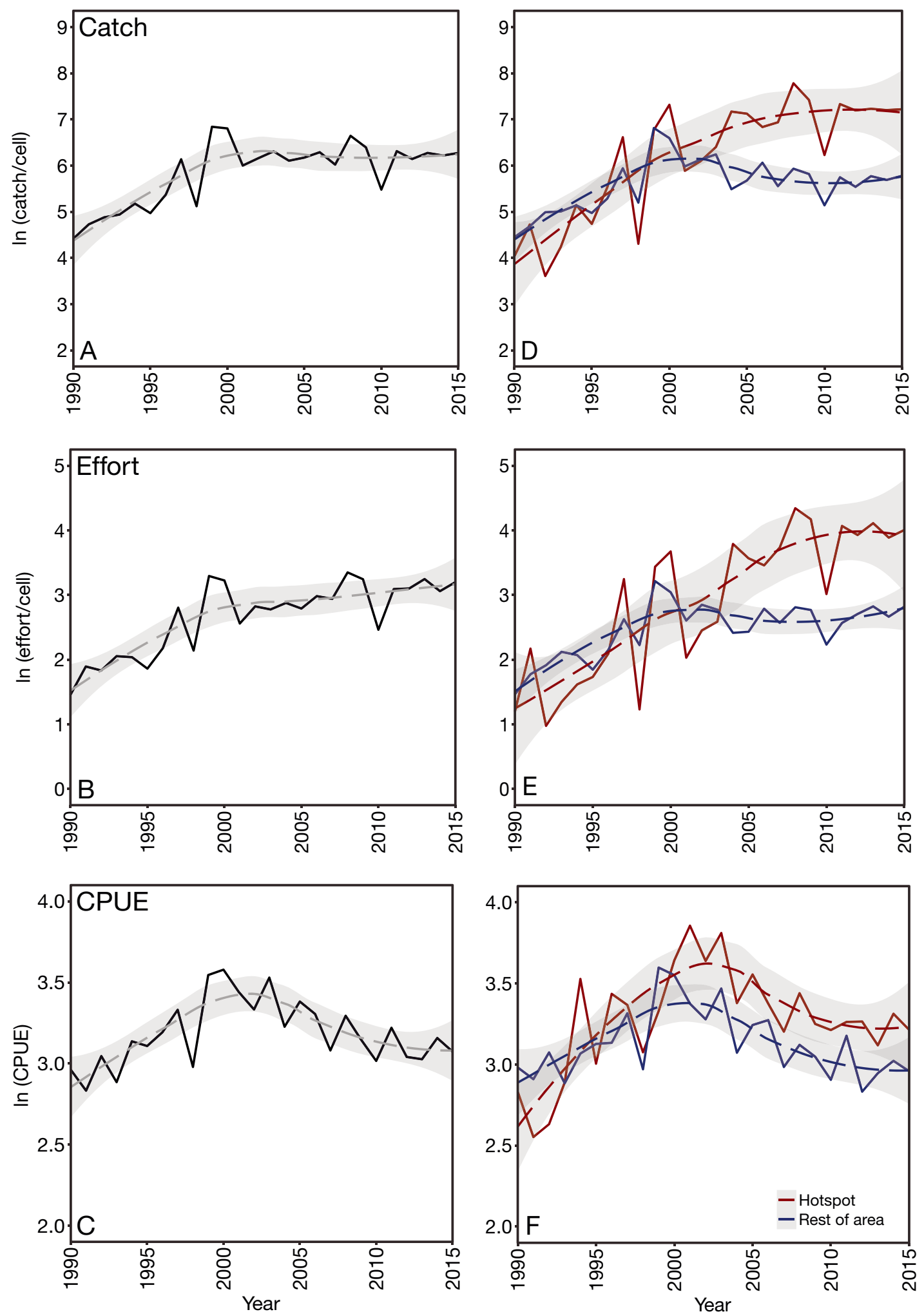

Fig. 3. Temporal trends in IATTC purse seine observer data. Shown is the natural logarithm of $(A, D)$ tuna catch, (B,E) fishing effort and (C,F) CPUE for tuna purse-seine fisheries from 1990-2015 across the entire study area (black lines in A-C) or differentiated between the fisheries hotspot (red lines) and the remainder of the study area (blue lines in D-F). Dashed lines and shaded area indicate polynomial regression model fit and $95 \%$ confidence interval, respectively. Note that trend lines diverge progressively after the marine reserve was enforced in 2002 
in the hotspot, we observed a $>200 \%$ increase of both average catch and fishing effort per $1^{\circ} \times 1^{\circ}$ grid cell, as well as a $7 \%$ increase of CPUE in the time period after Galápagos Marine Reserve enforcement relative to the preceding time period. In contrast, not taking the hotspot into account, CPUE decreased by $10 \%$ (catch increased by $2 \%$, fishing effort by $25 \%$ ). Fishing effort, catch, and CPUE from IATTC observer data aggregated at $1^{\circ} \times 1^{\circ}$ were not significantly correlated spatially (Moran's $I$ test: $\mathrm{SD}=-0.97, \mathrm{p}=$ 0.8341).

\section{AIS data}

Between January 2011 and October 2015, a total of 3391 AIS-carrying vessels passed through the study area, 66 of which were identified as purse seiners. This is about half the number of vessels carrying an IATTC observer and $24 \%$ of all purse seiners currently active and registered with IATTC for the Eastern Tropical Pacific (272 purse seine vessels in 2017). The vessels were flagged to 10 different nations with Ecuadorian vessels representing the majority $(27 \%)$. Fishing activity was detected for 49 of these vessels with a total of 664 fishing events or 'sets' (Fig. 1B). Vessel size ranged from $416 \mathrm{mt}$ up to $2799 \mathrm{mt}$. All vessels observed in the area were registered with IATTC.

The spatial patterns of purse seine sets extracted from the AIS data (Fig. 1) were non-randomly distributed (Nearest Neighbour Analysis, $z=-18.24$ ). Many sets were closely associated with the reserve boundary: density within the first $20 \mathrm{~km}$ around the reserve was at least 4 -fold larger than the average across the study area (Fig. 4). Across the entire fishing hotspot displayed in Fig. 2 (21 cells of varying distance to the reserve boundary), 170 purse seine fishing sets were detected using AIS, which represents twice the density of sets $(0.0006$ sets $\mathrm{km}^{-2}$ or 8.1 sets cell-1) in the hotspot compared with the rest of the study area $(0.0003$ sets $\mathrm{km}^{-2}$ or 4.02 sets cell ${ }^{-1}$ ) (Fig. 4).

Fishing effort per month varied strongly over the study period in both data sets with very few sets obtained from the AIS data during the years 2011 and 2012 and some months without any observed sets at all (Fig. S3 in the Supplement) likely due at least in part to poor satellite coverage at that time. The trends of fishing effort are similar in both data sets from 2012 onwards with peak fishing periods from January to July 2013 and June 2014 to January 2015.

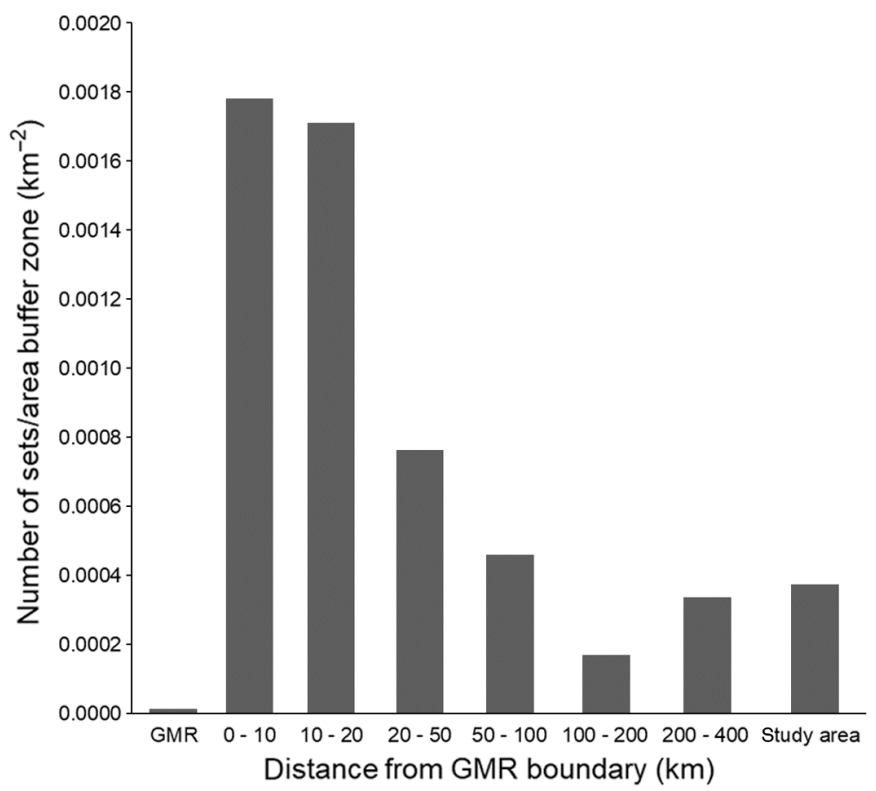

Fig. 4. 'Fishing the line'. Shown is the density of purse seine fishing sets detected by AIS tracking data 2011-2015, binned by distance from the marine reserve boundary. Note the remarkable aggregation of fishing effort within $20 \mathrm{~km}$ of the reserve boundary. Sets detected inside the Galápagos Marine Reserve (GMR) were also located very close to the boundary. Average density of sets for the total study area is displayed for comparison

\section{FAD data}

Between 1990 and 2015 a total of 95273 sets on tuna were recorded by IATTC within the study area with a total catch of 1907034 tons. About $36 \%$ of these sets were on floating objects or FADs (artificial and naturally occurring, Table S1 in the Supplement). The use of FADs in the study area has increased over the study period. In the time period from 1990 to $2002, \sim 10 \%$ of all sets were on FADs, whereas from 2003 to 2015, $26 \%$ were set on FADs. In contrast to the rest of the study area where the majority of sets have been on FADs between 2002 and 2015, most sets in the hotspot area (compare Fig. 1) are set on free schools (Fig. 5). Thus, while reliance on FADs has increased overall, this is seen to a much lesser extent in the areas with the most fishing effort and catch, i.e. the hotspot area adjacent to the marine reserve, indicating greater availability of free tuna schools.

Overall CPUE (tons per set) was higher on floating objects (25 tons per set) than on free schools or schools associated with dolphins (20 tons per set; Table S1 and Fig. S4 in the Supplement). CPUE has decreased for all sets and for sets only on floating objects between the 2 periods from 1990 to 2002 

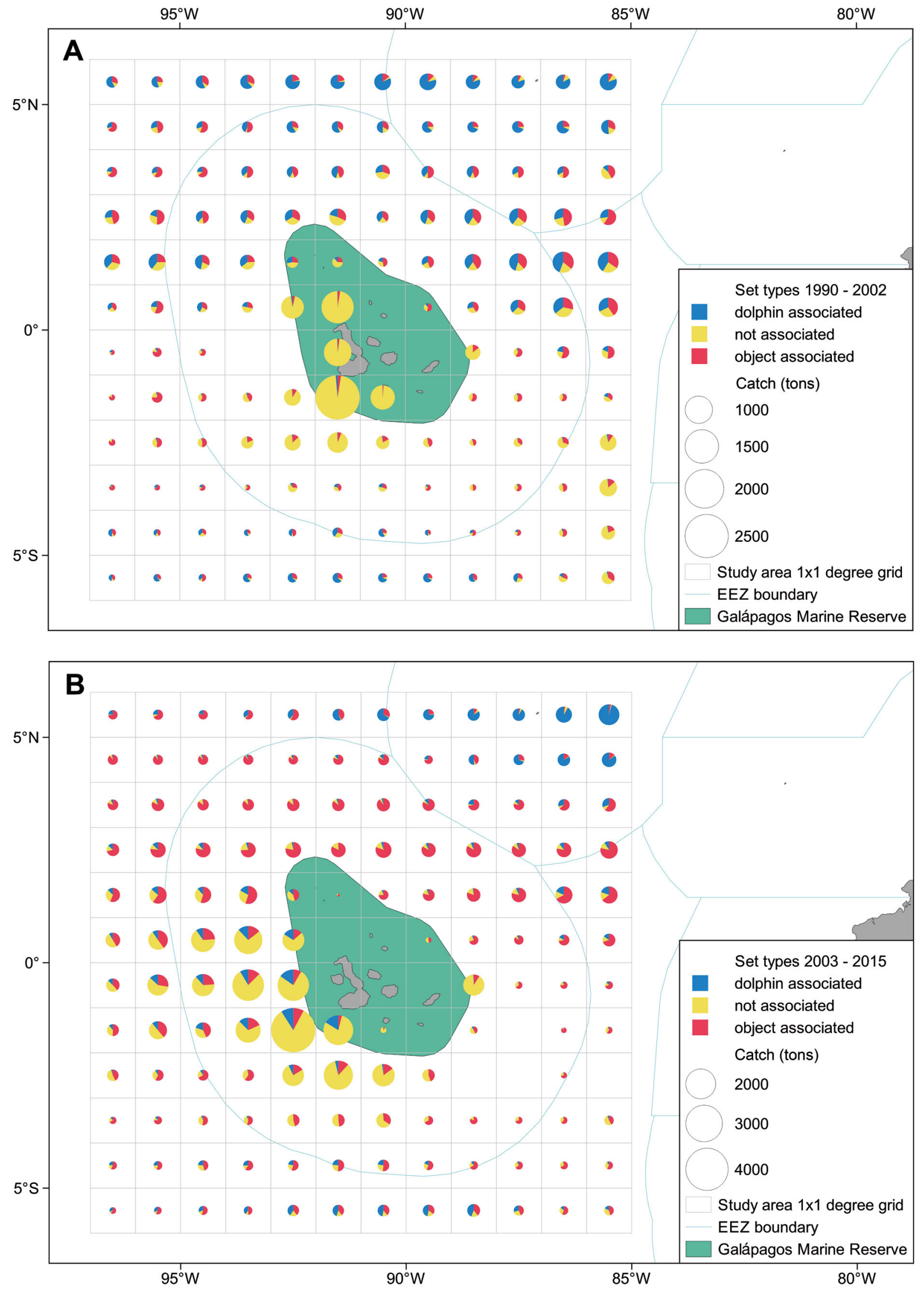
Fig. 5. Distribution of tuna purse seine set types. Types of tuna sets within the study area (grey grid) around the Galápagos Islands and the Galápagos Marine Reserve (green) before full enforcement of the reserve 1990-2002 (A) and after 2003-2015 (B). Note the increased proportion of sets on floating objects (red) as well as the number of sets not associated to objects or dolphins (yellow) to the west and southwest of the Galápagos Marine Reserve. Exclusive Economic Zone boundaries shown in light blue. Map data from Natural Earth and MarineRegions.org, Galápagos Marine Reserve shapefile from UNEP-WCMC and IUCN (2016)

(21 tons per set all sets and 32 tons per set floating objects only) and 2003 to 2015 (19.5 tons per set all sets and 23 tons per set floating objects only; Table S1). Although we cannot rule out that some FADs were set in such a way that they would drift through the reserve, collecting tuna along the way, no data exist that indicate such a practise.

\section{DISCUSSION}

Results of this study suggest that industrial tuna fisheries concentrate close to the Galápagos Marine reserve and that this area has been supporting higher catches, effort, and catch per unit of effort (CPUE) since reserve implementation and enforcement, but not before. While fisheries in the study area have increasingly relied on FADs to maintain viable catches, this practise has been much less commonly used in the fisheries hotspot close to the reserve, suggesting that larger, commercially viable free tuna schools still occur naturally in this area. The designation of the Galápagos Marine Reserve in 1998 initially met with strong, sometimes violent opposition (Denkinger \& Vinueza 2014, Kliffen \& Berkes 2015) until enforcement around 2002 ended decades of commercial fishing in the highly productive waters around the islands (Schiller et al. 2015). Yet, as fisheries have thrived closer to the reserve, local industry support for the Galápagos Marine Reserve has grown more recently (Kliffen \& Berkes 2015).

Our detailed analyses of vessel tracks, fishing locations, and type of purse seine sets indicate a direct association of fishing effort with the reserve boundary and progressively lower density of sets with increasing distance from the reserve (Fig. 4). In addition, overall fishing effort is increasingly concentrating around the reserve (Fig. 2) and in a regionally unique fisheries 'hotspot' west and southwest of the reserve, identified both in the IATTC observer and AIS data (Fig. 1, see Fig. S5 in the Supplement) as well as anecdotally by fishermen (Kliffen \& Berkes 2015, Martínez-Ortiz et al. 2015). This hotspot receives nearly 4 -fold greater density of fishing effort than the average for the study area and sustains higher catches and CPUE despite an increasing concentration of fishing effort (Fig. 2). The area features deeper waters and complex currents, creating upwelling and frontal areas (Liu et al. 2014) and represents favourable habitats for pelagic predators, most of which range throughout the whole Eastern Pacific (Fiedler et al. 1991, Miller 2007, Worm \& Tittensor 2011). It is now a preferred fishing ground for tuna purse seiners and longliners targeting mainly yellowfin Thunnus albacares and bigeye Thunnus obesus tuna as well as swordfish Xiphias gladius and a variety of sharks (Martínez-Ortiz et al. 2015). While effort increased in the hotspot, another fishing hotspot to the northeast of the reserve disappeared in the early 2000s (Fig. 2). It can be assumed that some of the vessels previously fishing in that area are now fishing closer to the boundary of the reserve. Whether they have changed fishing location in response to the establishment of the reserve or whether they respond to a change in oceanographic conditions or fish stock distribution remains unclear.

Fishing sets in the hotspot close to the reserve boundary are largely deployed on free-swimming schools of tuna, in contrast to surrounding areas where sets are commonly focused on floating objects such as artificial or naturally occurring FADs or schools associated with dolphins (Fig. 5). Free schools appear to be much more abundant along the reserve boundary and in the hotspot, reducing the need to rely on FADs. The majority of catch from sets on free schools has changed from yellowfin tuna to skipjack tuna Katsuwonus pelamis over the last decade. Skipjack tuna is also most commonly caught in sets on floating objects, followed by bigeye tuna (Miyake et al. 2010; Fig. S5).

Tuna stock availability in the hotspot appears to be higher than in surrounding waters of the wider region, attracting higher fishing effort, supporting higher catches, and dampening an overall declining CPUE trend (Fig. 3). Available stock assessments suggest that this trend might be connected to changing productivity regimes affecting recruitment and biomass trends, most notably for yellowfin tuna (Minte-Vera et al. 2014; Fig. S2). Following a strong recruitment peak around 1998 for all 3 main tuna species fished by purse seiners in the area (yellowfin, 
bigeye, and skipjack tuna), stock assessments show declining recruitment and subsequent loss of spawning stock biomass especially for yellowfin and bigeye tuna around the year 2002, contributing to declining catches in the following years (Aires-da-Silva \& Maunder 2014, Minte-Vera et al. 2014). Despite this overall productivity decline, after reserve implementation and subsequent enforcement in 2002, fishing effort and catches in the hotspot along the reserve boundary increased notably, in contrast to the rest of the study area (Fig. 3). While CPUE (and overall stock biomass) decreases gradually across the region after 2000, it remains higher in the hotspot after reserve enforcement. According to local ecological knowledge by fishermen, the area surrounding the Galápagos islands is believed to be a 'criadero', a tuna spawning and breeding ground (Kliffen \& Berkes 2015). Protection of habitats where vulnerable life stages aggregate, such as spawning grounds and nursery areas, is often assumed to produce disproportional reserve benefits (Halpern et al. 2004, Game et al. 2009). These factors might indicate a combination of favourable local environmental conditions and fisheries benefits that accrue downstream from a well-protected and well-placed reserve.

The use of previously unavailable high-resolution AIS data allowed us to investigate the fine-scale patterns of tuna fishing around the reserve, revealing close attraction of fishing effort to the immediate reserve boundary (Fig. 4) which received $>4$-fold greater density of sets than the area from 20 to $400 \mathrm{~km}$ from the boundary (Fig. 4, Fig. S3). The hotspot lies downstream from predominant east-west currents, which may transport adult tuna as well as larvae and juveniles into the hotspot area (Reglero et al. 2014). Fisheries here potentially benefit from a spillover effect, explaining higher catches in the hotspot despite increasing effort (Fig. 3). 'Fishing the line' behaviour has been observed around other spatial closures and is a potential indicator for spillover benefits in the form of more fish leaving the reserve that are available to fisheries nearby (Rijnsdorp et al. 1998, Johnson et al. 1999, Murawski et al. 2005, Kellner et al. 2007, Russ \& Alcala 2011, Alemany et al. 2013, Van Der Lee et al. 2013). Spillover benefits in the area have been explicitly recognised by fishermen interviewed in a qualitative study by Kliffen \& Berkes (2015). The declining CPUE trends overall, however, might indicate that any reserve spillover is not pronounced enough to reverse overall biomass trajectories for the region as indicated by relevant stock assessments (Aires-da-Silva \& Maunder 2014, Minte-Vera et al. 2014).
The long-term trends discussed here are superimposed on large inter-annual fluctuations in fishing effort, catch, and CPUE as seen in the IATTC data (Fig. S1). These fluctuations are likely controlled by a number of factors, related to fleet behaviour, seasonality (Sweet et al. 2007), and the strong variability associated with regional climate fluctuations, namely the El Niño-Southern Oscillation (ENSO) (Lehodey 2000) and Pacific Decadal Oscillation (Worm et al. 2005). In addition, fisheries management influences the distribution of purse seine vessels through periodic time-area closures for industrial purse seiners enforced since the early 2000s (Maunder \& Harley 2006), potentially contributing to observed shifts in fishing effort (Fig. 2). Temporal closures are known to affect spatial as well as temporal dynamics of fishing effort and can lead to an intensification of fishing effort along closure boundaries and in closure areas especially after the seasonal opening of the closed zone (Murawski et al. 2005). For example, monthly set data from both IATTC and AIS show that purse seiners abide by a first fishing closure period August and September, but remain partially active during a second closure period from November to January (Fig. S4).

Through the combination of long-term, large-scale observer data and short-term, fine-scale AIS data, we were able to obtain a reasonably comprehensive picture of purse seine fishing fleet behaviour around the Galápagos Marine Reserve. Vessel monitoring using on-board observers has a long tradition and is ideal to obtain not only information about the activities of the fishing vessel but also detailed information on the catch. However, this method is limited by the numbers of observers available, the proprietary nature of the data, and the coarse scale at which data are reported. AIS, especially satellite AIS, is an emerging tool in fishing vessel monitoring and surveillance (Cairns 2005, Carson-Jackson 2012, McCauley et al. 2016). While the system does not provide data on catches, vessels carrying an AIS transponder can be tracked on a fine scale in any part of the ocean. Data transmission is only limited by the number of vessels carrying AIS transponders and the number of satellites in an area receiving the AIS signals. Due to the differences in information transmitted with each dataset, the observer data and the AIS data are highly complementary and well-suited to be combined and contrasted as shown here. There have been increasing calls to make AIS use mandatory for all fishing vessels, and as such to create a more detailed and comprehensive picture of vessel activity that can be used by Regional Fisheries Management 
Organizations and other stakeholders (McCauley et al. 2016).

However, some important caveats and limitations remain: while observer coverage reaches $100 \%$ for IATTC capacity class 6 vessels in the last years (InterAmerican Tropical Tuna Commission 2017), some smaller vessels do not carry an observer on board. Likewise, AIS coverage is now mandatory for all fishing vessels operating a motor within the Galápagos Marine Reserve; however, this regulation was only imposed in 2015. Small and artisanal vessels $<10$ tons and some industrial vessels $<300$ gross tonnage remain largely undocumented in both the IATTC and the AIS data sets. Furthermore, AIS vessel tracks can be incomplete due to insufficient satellite coverage, and the AIS transponder can be manipulated, e.g. track locations or vessel identities can be manually altered. AIS data might therefore require some preprocessing.

Notwithstanding these inherent limitations, this is, to our knowledge, the first study examining interactions between a large MPA and an associated pelagic fishery. Many of the interactions seen in this study are likely shaped by the unique context and local factors such as oceanographic features and regional fisheries management; however, some patterns like the fishing the line have been seen for other, mostly smaller MPAs around the world (e.g. Murawski et al. 2005). While this work aims to explore an in-depth case study, a comprehensive analysis comparing interactions of fisheries with large MPAs more generally would be desirable.

\section{CONCLUSION}

In this study, the combination of on-board observer and satellite AIS tracking data provided a detailed picture of vessel behaviour, fishing effort, and catches in the Eastern Tropical Pacific and could be utilized more generally to monitor fisheries and conservation outcomes of large marine reserves in real time. We found that tuna purse seine vessels have reacted to the establishment of the Galápagos Marine Reserve and are increasingly fishing along the boundary of the reserve. Possibly due to a combination of reserve benefits on local stock availability and favourable habitat in this hotspot, tuna catches are higher than in surrounding areas since reserve enforcement, and fisheries there rely much less on the use of fish aggregating devices than in surrounding areas. These apparent benefits to fishers were realized despite an overall increase of fishing effort and declining tuna recruitment and productivity across the wider region. In aggregate, these results suggest that the Galápagos Marine Reserve has a net positive effect on associated pelagic fisheries and supports the case for establishing large-scale marine protected areas both as fisheries management and biodiversity conservation tools.

Acknowledgements. We gratefully acknowledge N. Vogel and R. Deriso who provided the IATTC observer data and graciously supported this study with their expertise. Likewise, we wish to thank AIS data provider exactEarth Ltd. 2016, in collaboration with the Marine Environmental Observation, Prediction and Response Network (MEOPAR). The work was partially supported by the NSERC CREATE Transatlantic Ocean System Science and Technology (TOSST) Program and an NSERC Discovery grant to B.W. S. Henderson and M. Castrejón provided valuable insights in the context of the Galápagos Islands. We are grateful for the help of a team of volunteers at Dalhousie University supporting the identification of vessel types.

\section{LITERATURE CITED}

Aires-da-Silva A, Maunder MN (2014) Status of bigeye tuna in the Eastern Pacific Ocean in 2014 and outlook for the future. IATTC Stock assessment report. IATTC, La Jolla, CA. www.iattc.org/PDFFiles2/StockAssessmentReports/ SAR16/1-BET-assessment-2014.pdf

Alemany D, Iribarne OO, Acha EM (2013) Effects of a largescale and offshore marine protected area on the demersal fish assemblage in the Southwest Atlantic. ICES J Mar Sci 70:123-134

Kreen P, Posen P, Righton D (2015) Temperate Marine Protected Areas and highly mobile fish: a review. Ocean Coast Manage 105:75-83

* Buxton CD, Hartmann K, Kearney R, Gardner C (2014) When is spillover from marine reserves likely to benefit fisheries? PLOS ONE 9:e107032

Cairns WR (2005) AIS and long range identification \& tracking. J Navig 58:181-189

* Carson-Jackson J (2012) Satellite AIS-developing technology or existing capability? J Navig 65:303-321

* Castrejón M, Charles A (2013) Improving fisheries comanagement through ecosystem-based spatial management: the Galapagos Marine Reserve. Mar Policy 38: 235-245

Collette BB, Carpenter KE, Polidoro BA, Boustany A and others (2011) High value and long life-double jeopardy for tunas and billfishes. Science 333:291-292

* da Silva IM, Hill N, Shimadzu H, Soares AMVM, Dornelas M (2015) Spillover effects of a community-managed marine reserve. PLOS ONE 10:e0111774

de Souza EN, Boerder K, Matwin S, Worm B (2016) Improving fishing pattern detection from satellite AIS using data mining and machine learning. PLOS ONE 11:e0158248

Denkinger J, Vinueza L (eds) (2014) The Galapagos Marine Reserve: a dynamic social-ecological system. Springer, New York, NY

* Dudley N (2008) Guidelines for applying protected area management categories. IUCN, Gland

Edgar GJ, Stuart-Smith RD, Willis TJ, Kininmonth S and 
others (2014) Global conservation outcomes depend on marine protected areas with five key features. Nature 506:216-220

Fiedler PC, Philbrick V, Chavez FP (1991) Oceanic upwelling and productivity in the eastern tropical Pacific. Limnol Oceanogr 36:1834-1850

Follesa MC, Cannas R, Cau A, Cuccu D and others (2011) Spillover effects of a Mediterranean marine protected area on the European spiny lobster Palinurus elephas (Fabricius, 1787) resource. Aquat Conserv 21:564-572

Forcada A, Bayle-Sempere JT, Valle C, Sánchez-Jerez P (2008) Habitat continuity effects on gradients of fish biomass across marine protected area boundaries. Mar Environ Res 66:536-547

Game ET, Grantham HS, Hobday AJ, Pressey RL and others (2009) Pelagic protected areas: the missing dimension in ocean conservation. Trends Ecol Evol 24:360-369

Gell FR, Roberts CM (2003) Benefits beyond boundaries: the fishery effects of marine reserves. Trends Ecol Evol 18: 448-455

Goñi R, Adlerstein S, Alvarez-Berastegui D, Forcada A and others (2008) Spillover from six western Mediterranean marine protected areas: evidence from artisanal fisheries. Mar Ecol Prog Ser 366:159-174

Grüss A, Kaplan DM, Guénette S, Roberts CM, Botsford LW (2011) Consequences of adult and juvenile movement for marine protected areas. Biol Conserv 144:692-702

Halpern BS, Gaines SD, Warner RR (2004) Confounding effects of the export of production and the displacement of fishing effort from marine reserves. Ecol Appl 14: 1248-1256

*Horta e Costa B, Batista MI, Gonçalves L, Erzini K, Caselle JE, Cabral HN, Gonçalves EJ (2013) Fishers' behaviour in response to the implementation of a marine protected area. PLOS ONE 8:e65057

Hyrenbach KD, Forney KA, Dayton PK (2000) Marine protected areas and ocean basin management. Aquat Conserv 10:437-458

Inter-American Tropical Tuna Commission (2017) Document IATTC-92 INF-A Safety at sea for IATTC and AIDCP observers on tuna purse-seine vessels. Mexico City, Mexico. www.iattc.org/Meetings/Meetings2017/IATTC92/PDFs/Docs/_English/IATTC-92-INF-A_Observersafety-at-sea.pdf

*Jensen OP, Ortega-Garcia S, Martell SJD, Ahrens RNM, Domeier ML, Walters CJ, Kitchell JF (2010) Local management of a 'highly migratory species': the effects of long-line closures and recreational catch-and-release for Baja California striped marlin fisheries. Prog Oceanogr 86:176-186

Johnson DR, Funicelli NA, Bohnsack JA (1999) Effectiveness of an existing estuarine no-take fish sanctuary within the Kennedy Space Center, Florida. N Am J Fish Manage 19:436-453

* Juan-Jordá MJ, Mosqueira I, Cooper AB, Freire J, Dulvy NK (2011) Global population trajectories of tunas and their relatives. Proc Natl Acad Sci USA 108:20650-20655

Kellner JB, Tetreault I, Gaines SD, Nisbet RM (2007) Fishing the line near marine reserves in single and multispecies fisheries. Ecol Appl 17:1039-1054

Kelly S, Scott D, MacDiarmid AB, Babcock RC (2000) Spiny lobster, Jasus edwardsii, recovery in New Zealand marine reserves. Biol Conserv 92:359-369

Kliffen N, Berkes J (2015) Catch 22-The Galapagos Marine Reserve from a tuna fishery perspective. World
Wildlife Fund, Quito

Lehodey P (2000) Impacts of the El Niño Southern Oscillation on tuna populations and fisheries in the tropical Pacific Ocean. Secretariat of the Pacific Community, Noumea

ํLiu Y, Xie L, Morrison JM, Kamykowski D, Sweet WV (2014) Ocean circulation and water mass characteristics around the Galápagos Archipelago simulated by a multiscale nested ocean circulation model. Int J Oceanogr 2014: $1-16$

Lubchenco J, Grorud-Colvert K (2015) Making waves: the science and politics of ocean protection. Science 350: 382-383

* Martínez-Ortiz J, Aires-da-Silva AM, Lennert-Cody CE, Maunder MN (2015) The Ecuadorian artisanal fishery for large pelagics: species composition and spatio-temporal dynamics. PLOS ONE 10: e0135136

Maunder MN (2014) Status of skipjack tuna in the Eastern Pacific Ocean in 2014. Bulletin of the Inter-American Tropical Tuna Commission, p 32-54

Maunder MN, Harley SJ (2006) Evaluating tuna management in the eastern Pacific Ocean. Bull Mar Sci 78: 593-606

*McCauley DJ, Woods P, Sullivan B, Bergman B and others (2016) Ending hide and seek at sea. Science 351: 1148-1150

*McClanahan TR, Mangi S (2000) Spillover of exploitable fishes from a marine park and its effect on the adjacent fishery. Ecol Appl 10:1792-1805

* Miller KA (2007) Climate variability and tropical tuna: management challenges for highly migratory fish stocks. Mar Policy 31:56-70

Minte-Vera CV, Aires-da-Silva A, Maunder MN (2014) Status of yellowfin tuna in the Eastern Pacific Ocean in 2014 and outlook for the future. IATTC Stock assessment report. IATTC, La Jolla, CA. www.iattc.org/PDFFiles2/ StockAssessmentReports/SAR16/2-YFT-assessment-2014. pdf

Miyake MP, Guillotreau P, Sun C, Ishimura G (2010) Recent developments in the tuna industry: stocks, fisheries, management, processing, trade and markets. United Nations Food and Agriculture Organization, Rome. www.fao.org/3/a-i1705e.pdf

Murawski S, Brown R, Lai HL, Rago PJ, Hendrickson L (2000) Large-scale closed areas as a fishery-management tool in temperate marine systems: the Georges Bank experience. Bull Mar Sci 66:775-798

Murawski SA, Wigley SE, Fogarty MJ, Rago PJ, Mountain DG (2005) Effort distribution and catch patterns adjacent to temperate MPAs. ICES J Mar Sci 1167:1150-1167

Myers RA, Worm B (2003) Rapid worldwide depletion of predatory fish communities. Nature 423:280-283

Oxford P, Watkins G, Philip P (2009) Galapagos: both sides of the coin. Enfoque Ediciones, Quito

Pons M, Branch TA, Melnychuk MC, Jensen OP and others (2017) Achimer Effects of biological, economic and management factors on tuna and billfish stock status. Fish Fish 18:1-21

* Reglero P, Tittensor DP, Álvarez-Berastegui D, AparicioGonzález A, Worm B (2014) Worldwide distributions of tuna larvae: revisiting hypotheses on environmental requirements for spawning habitats. Mar Ecol Prog Ser 501:207-224

* Rijnsdorp AD, Buys AM, Storbeck F, Visser EG (1998) Micro-scale distribution of beam trawl effort in the 
southern North Sea between 1993 and 1996 in relation to the trawling frequency of the sea bed and the impact on benthic organisms. ICES J Mar Sci 55:403-419

Roberts CM, Bohnsack JA, Gell F, Hawkins JP, Goodridge R (2001) Effects of marine reserves on adjacent fisheries. Science 294:1920-1923

Russ GR, Alcala AC (2011) Enhanced biodiversity beyond marine reserve boundaries: the cup spillith over. Ecol Appl 21:241-250

Schiller L, Alava JJ, Grove J, Reck G, Pauly D (2015) The demise of Darwin's fishes: evidence of fishing down and illegal shark finning in the Galápagos Islands. Aquat Conserv 25:431-446

Stevenson TC, Tissot BN, Walsh WJ (2013) Socioeconomic consequences of fishing displacement from marine protected areas in Hawaii. Biol Conserv 160:50-58

Stobart B, Warwick R, González C, Mallol S, Díaz D, Reñones O, Goñi R (2009) Long-term and spillover effects of a marine protected area on an exploited fish community. Mar Ecol Prog Ser 384:47-60

Sweet WV, Morrison JM, Kamykowski D, Schaeffer BA, Banks S, McCulloch A (2007) Water mass seasonal variability in the Galapagos Archipelago. Deep Sea Res I 54: 2023-2035

Tawake A, Parks J, Radikedike P, Aalbersberg B, Vuki V, Salafsky N (2001) Harvesting clams and data involving local communities in monitoring can lead to conservation success in all sorts of unanticipated ways: a case in Fiji. Conservation 2:32-35

Editorial responsibility: Tim McClanahan, Mombasa, Kenya
Tewfik A, Babcock E, Gibson J, Burns Perez V, Strindberg S (2017) Benefits of a replenishment zone revealed through trends in focal species at Glover's Atoll, Belize. Mar Ecol Prog Ser 580:37-56

*UNEP-WCMC and IUCN (2016) Protected planet: the world database on protected areas (WDPA) 05/2016, UNEPWCMC and IUCN, Cambridge. www.protectedplanet. net

* Van Der Lee A, Gillis DM, Comeau P, Hurley P and others (2013) Fishing the line: catch and effort distribution around the seasonal haddock (Melanogrammus aeglefinus) spawning closure on the Scotian Shelf. Can J Fish Aquat Sci 70:973-981

Walker E, Bez N (2010) A pioneer validation of a state-space model of vessel trajectories (VMS) with observers' data. Ecol Modell 221:2008-2017

White TD, Carlisle AB, Kroodsma DA, Block BA and others (2017) Assessing the effectiveness of a large marine protected area for reef shark conservation. Biol Conserv 207: $64-71$

*Wilhelm T'A, Sheppard CRC, Sheppard ALS, Gaymer CF, Parks J, Wagner D, Lewis N (2014) Large marine protected areas - advantages and challenges of going big. Aquat Conserv: Mar Freshw Ecosyst 24:24-30

*Worm B, Tittensor DP (2011) Range contraction in large pelagic predators. Proc Natl Acad Sci USA 108:11942-11947

* Worm B, Sandow M, Oschlies A, Lotze HK, Myers RA (2005) Global patterns of predator diversity in the open oceans. Science 309:1365-1369

Submitted: January 16, 2017; Accepted: October 27, 2017 Proofs received from author(s): December 5, 2017 